\title{
SURFACE FINISH IN TURNING OF NODULAR CAST IRON USING COATED CARBIDE AND SILICON NITRIDE CERAMIC TOOLS
}

\author{
Wit Grzesik, Krzysztof Żak, Sebastian Brol \\ Department of Manufacturing Engineering and Production Automation, Opole University of Technology, P.O. \\ Box 321, 45-271 Opole, Poland \\ e-mail address: w.grzesik@po.opole.pl
}

In this paper the surface finish produced by turning of perlitic-ferritic nodular cast iron (NCl) with multilayer $\left(\mathrm{TiC} / \mathrm{Ti}(\mathrm{C}, \mathrm{N}) / \mathrm{Al}_{2} \mathrm{O}_{3} / \mathrm{TiN}\right)$ coated $\mathrm{P2O}$ carbide and nitride ceramic cutting tools is characterized using both 2D and 3D roughness parameters. The surface finish was characterized using a set of surface roughness parameters including vertical $(R a, R z, R t)$, horizontal $(R S m)$, hybrid $(R \Delta q)$, and additionally statistical (RSk, RKu) and functional parameters based on the bearing curve (Rmr(c) Rpk, Rvk, Rk). Some 3D roughness parameters were also considered and compared with 2D parameters. The data obtained can support the optimization of finishing operations of $\mathrm{NCl}$ parts.

Key words: nodular cast iron, surface finish, coated carbide tools, silicon nitride ceramic tools

\section{References}

[1] Schulz, H., Reuter U. (2001). Verschleißmechanismus geklärt: GGV-Motoren reif für die Großserie, Werkstatt und Betrieb, 134/7-8: 80-82.

[2] Byrne, G., Dornfeld D., Denkena B. (2003). Advancing cutting technology, Annals of CIRP, 52/2: 483-507.

[3] Momper, F.J. (1998). Neue Schneidstoffe für neue Werkstoffe, Werkstatt und Betrieb, 131/5: 390-394.

[4] Graham, D. (2006). Machining cast iron, Manufacturing Engineering, 136/2.

[5] Nodular iron. Classification, Polish and European Standard PN-EN 1563:2000.

[6] Grzesik, W. (2003). Advanced Protective Coatings for Manufacturing and Engineering, Cincinnati, Hanser Gardner Publ.

[7] Grzesik W. (2008). Advanced machining processes of metallic materials, Amsterdam, Elsevier.

[8] Yigit R., Celik E., Findik F., Koksal S. (2008). Effect of cutting speed on the performance of coated and uncoated cutting tools in turning nodular cast iron, J. Mater. Proc. Technol., 204: 80-88.

[9] Ghani A.K., Choudhury I.A., Husni (2002). Study of tool life, surface roughness and vibration in machining nodular cast iron with ceramic tool, J. Mater. Proc. Technol., 127, 17-22.

[10] Grzesik W., Rech J., Zak K., Claudin C. (2009). Machining performance of pearlitic-ferritic nodular cast iron with coated carbide and silicon nitride cutting tools, Int. J. Mach. Tools Manuf., 49/2, 125-133.

[11] Grzesik W., Wanat T (2005). Comparative assessment of surface roughness produced by hard machining with mixed ceramic tools including 2D and 3D analysis, J. Mater. Proc. Technol., 169, 364-371. 